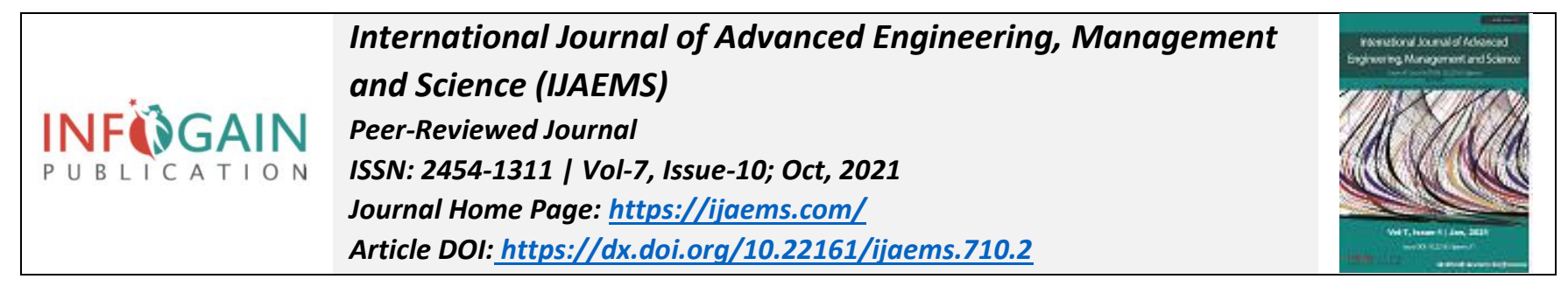

\title{
Margin Analysis of Marketing, Julung-Julung Fish (Hyporhamphus Affinis), in Kinabuhutan Village, West Likupang District, North Minahasa Regency
}

\author{
Siti Suhaeni; Srie J. Sondakh; Olvie V. Kotambunan
} Faculty of Fisheries and Marine Sciences, University of Sam Ratulangi Manado, Indonesia
Corresponding Author: 1 sitisuhaeni@unsrat.ac.id

Received: 16 Sep 2021; Received in revised form: 10 Oct 2021; Accepted: 16 Oct 2021; Available online: 24 Oct 2021

\begin{abstract}
The purpose of this study was to determine the number of marketing channels and the amount of margin in each marketing channel to determine the efficiency of marketing and the added value received by each marketing actor of Julung-Julung fish in Kinabuhutan Village. The population in this study were fishermen catching julung-julung fish, fish processors, middlemen and retailers. Data was collected using the census method for fishermen and fish processors, while traders used purposive sampling. The data collected in the form of primary data and secondary data. Primary data collection techniques with observation and interviews. The data obtained were analyzed using quantitative descriptive analysis and qualitative descriptive analysis. Quantitative descriptive analysis using marketing margin analysis.

Based on the research results, it is known that there are only 2 marketing channels for fresh julung-julung fish in Kinabuhuta Village, namely from fishermen to consumers and from fishermen to fish processors. Both channels have a marketing margin of 0 which means that the channel is efficient because the price paid by consumers is the same as that received by fishermen. The marketing channels for smoked JulungJulung fish are 4 marketing channels with marketing areas, Kinabuhutan, Likupang, Bitung, Airmadidi, Manado and Tomohon. Based on the results of the margin analysis, it is known that the farther the distance between producers and consumers, the longer the marketing channel and the larger the marketing margin, making it more inefficient. In this study, the marketing channel no. 1 with the marketing area to Tomohon is inefficient because the price paid by the final consumer is the most expensive so that the largest marketing margin is Rp. 12,000,-. While the most efficient which is marketed in the production area is channel 4 because the margin is 0 . The added value received by fishermen is Rp. 4,500, -. Per 20 fish, the fish processing producer is $R p .7,850,-$, while the middlemen and retailers vary according to the marketing area. The lowest marketing costs are those that are marketed in the production area in Kinabuhutan, namely 0 and the largest is the farthest, Tomohon.
\end{abstract}

Keywords_-Julung-Julung fish, Marketing margin, Kinabuhutan.

\section{INTRODUCTION}

Problems in the field of marketing that need immediate attention are related to efficiency and marketing margins for fishery products especially capture fisheries. Fishermen have had a low bargaining position compared to middlemen who have market information. The greater the difference between the price at the fisherman's level and the price paid by the final consumer is an indication that the marketing channel is increasingly inefficient and the fisherman receives a smaller share. The family's economic limitations require women fishermen, including their children, to work in coastal areas.

Kinabuhutan is a village located on a small island in the West Likupang sub-district, North Minahasa Regency, North Sulawesi Province. The majority of the residents of Kinabuhutan Village work as fishermen, so that the people 
of Kinabuhutan Village depend on marine products for their lives. The marketing of the catches of fishermen in Kinabuhutan Village is very influential on the economy.

In the fishery product marketing system, there is a conflict of interest from three main pillars, namely producers who want high prices, while consumers want low prices and marketing institutions that want maximum profits. The problem then is that in the marketing of fishery commodities, especially Julung-Julung fish, based on empirical studies, it is shown that the parties who are most disadvantaged are fishermen, while traders in general get bigger profits or in other words the market system is still far from the principle of justice. Marketing efficiency is the main base of the objectives to be achieved in any fishery product marketing system. In general, a marketing system is said to be efficient if it is able to deliver products from the producer level to the hands of final consumers by satisfying the interests of all stakeholders in marketing fairly according to the level of their respective sacrifices. From this description, it is very important to conduct a study of how much margin the fishermen receive in each marketing channel of julung-julung fish in Kinabuhutan Village.

This study aims to determine the number of marketing channels and the amount of margin in each marketing channel to determine the efficiency of marketing and the added value received by each marketing actor of JulungJulung fish in Kinabuhutan Village. It is hoped that this research can increase fishermen's awareness of the importance of knowing the margins in each marketing channel. The smaller the marketing margin, the more efficient the marketing chain, so that it can lead to an increase in fishermen's income which will be followed by an increase in the welfare of the people in Kinabuhutan Village in general and fishermen in particular.

\section{RESEARCH METHODS}

The basis of this research is survey research. The survey method is a research conducted to obtain facts from existing phenomena and to seek factual information, whether about institutions, social, economic, or political aspects of a group or an area (Nazir 2003).

The population in this study was divided into 4 groups, namely Julung-Julung fishermen, Smoked JulungJulung fish processors, middlemen and retailers. The total population of fishermen owners is 31 people so that a $50 \%$ sample is taken, namely 16 people using random sampling, the population of Julung-Julung fish processors is only 3 people so that all of them are taken or use the census method, while for middlemen and retailers using purposive sampling method, namely only take 1 middleman and 1

This article can be downloaded from here: $w$ ww.ijaems.com

(C)2021 The Author(s). Published by Infogain Publication.

This work is licensed under a Creative Commons Attribution 4.0 License. http://creativecommons.org/licenses/by/4.0/ retailer in each marketing channel based on the city of marketing destination. The data collected is in the form of primary data and secondary data. Primary data was collected through observation and interviews guided by questionnaires, while secondary data was collected by citing existing data at the village office and other agencies related to this research.

The data analysis used is quantitative descriptive analysis and qualitative descriptive analysis. Qualitative descriptive analysis is data processing that is carried out through logical considerations with systematic author languages. The analyzed data is then interpreted with logical considerations using the author's systematic languages by referring to references related to research results, journals (Fathoni, 2006). While quantitative descriptive analysis uses Margin Analysis

\section{Calculating Marketing Margin (Hanafiah, 1986)}

$$
\mathbf{M i}=\mathbf{H i}-\mathbf{H i}-\mathbf{1}
$$

description:

Mi = Margin at the 1st intermediary trader caught by fisherman A (Rp/unit)

Hi = Selling price of the 1st intermediary trader caught by Fisher A(Rp/unit)

Hi-1= Purchase price of the 1st intermediary trader caught by Fisher A (Rp/unit)

\section{Calculating Total Marketing Profits (Hanafiah, 1986)}

$$
\mathbf{K M}=\mathbf{M P}-\mathbf{B P}
$$

description:

$$
\begin{aligned}
& \mathbf{K M}=\text { Total marketing profit (Rp/unit) } \\
& \mathbf{M P}=\text { Marketing Margin (Rp/unit) } \\
& \mathbf{B P}=\text { Total marketing costs (Rp/unit) }
\end{aligned}
$$

\section{RESEARCH RESULT}

\section{State of the research area}

Kinabuhutan Village is one of the coastal villages located on a small island called Kinabuhutan Island and is included in the Likupang Barat sub-district, North Minahasa Regency. The average population of Kinabuhutan Village works as a fisherman and most of them are traditional fishermen. One of the catches of fishermen in Kinabuhutan Village is Julung-Julung fish or in the local language called Roa fish. The catch obtained by fishermen must be marketed as soon as possible 


\section{Marketing Margin at fisherman level}

There are 329 fishermen in Kinabuhutan Village with 31 fishing boat owners and each only owns one fishing boat. Usually in one fishing boat unit it takes 7 to 10 fishermen as crew members
The cost of catching fish in Kinabuhutan Village consists of fixed costs and variable costs. Fixed costs are depreciation costs and maintenance costs for investment items such as boats or ships, nets, machines and others. The composition of fixed costs incurred is as shown in table 1 .

Table 1. Fixed Costs of Julung-Julung Fishing Business (H. brasiliensis) per Trip

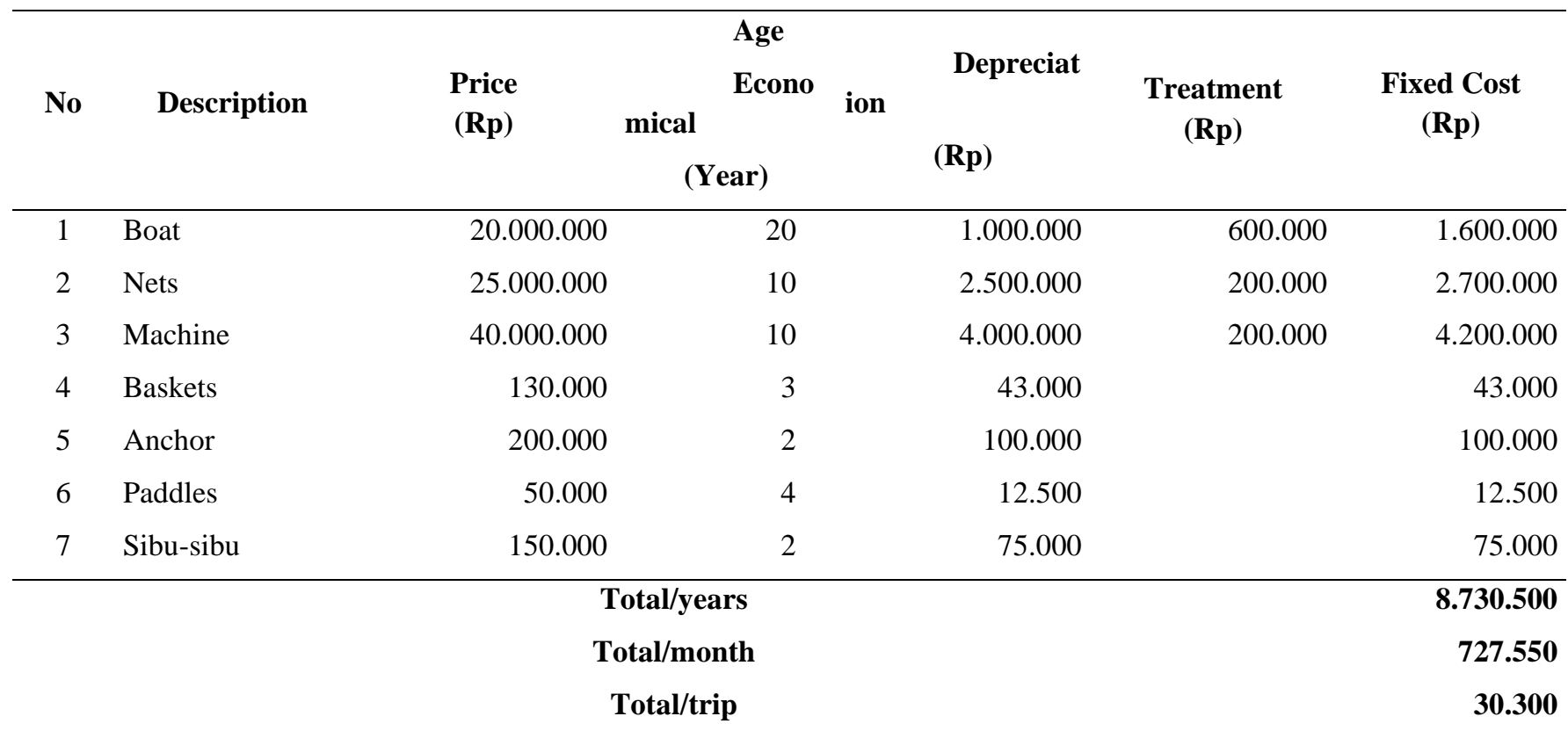

Source: Primary Data Processed, 2020

Variable costs are the total costs incurred to obtain factors of production that can be changed in number. Variable costs in the fishing effort of julung-julung ( $\mathrm{H}$. brasiliensis) can be seen in Table 2

Table 2. Variable costs per trip in the Julung-Julung ( $H$. brasiliensis) Fishing Business.

\begin{tabular}{lll}
\hline No & Description & Variable cost \\
\hline 1 & Labor wages & 126.000 .000 \\
2 & BBM @ Rp.10.000 & 24.000 .000 \\
3 & Water refill@ Rp.10.000 & 960.000 \\
4 & Coolbox @ Rp.35000 & 105.000 \\
\hline Total/year & $\mathbf{1 5 1 . 0 6 5 . 0 0 0}$ \\
Total/month & $\mathbf{1 2 . 5 8 8 . 7 5 0}$ \\
Total/trip & $\mathbf{5 2 4 . 5 3 1}$
\end{tabular}

Source: Primary Data Processed, 2020

The total cost is the total cost incurred in the fishing business of Julung-Julung ( $\mathrm{H}$. brasiliensis). The total cost per trip is calculated by adding up the fixed costs per trip and variable costs per trip so that the results are as shown in table 3

This article can be downloaded from here: $w w w . i j a e m s . c o m$

(C)2021 The Author(s). Published by Infogain Publication.

This work is licensed under a Creative Commons Attribution 4.0 License. http://creativecommons.org/licenses/by/4.0/
Table 3. Total cost per head of the Julung-Julung ( $H$. brasiliensis)

\begin{tabular}{|c|c|c|}
\hline No & Description & Amount (Rp) \\
\hline 1 & Fixed Fee (Rp) & 30.300 \\
\hline 2 & Variable Costs(Rp) & 524.531 \\
\hline & Total/trip (Rp) & $\mathbf{5 5 4 . 8 3 1}$ \\
\hline & Average result per trip (tail) & 11.250 \\
\hline Total & Cost per head (Rp) & 49,3183 \\
\hline
\end{tabular}

Source: Primary Data Processed, 2020

The total catch of fishermen per trip is at least 500 fish and at most 20,000 fish so that the average catch per trip is 11,250 fish so that the costs incurred to catch a crayfish are $\mathrm{Rp}$. 554,831 divided by 11,250 which is Rp.49,3183 or rounded up to Rp.50,-. The catch of julung-julung fish is sold per head for Rp. 500, -. Thus the fishermen get a profit of Rp. 450, - per fish.

The catch of julung-julung fish in Kinabuhutan Village is only marketed in Kinabuhutan Village, because it is constrained by the perishable nature of the fish and

20 
the small and traditional scale of production of the catch and the limited financial position of fishermen.

Based on the results of the analysis above, it is known that there are only 2 marketing channels for fresh julungjulung fish caught by fishermen that is :

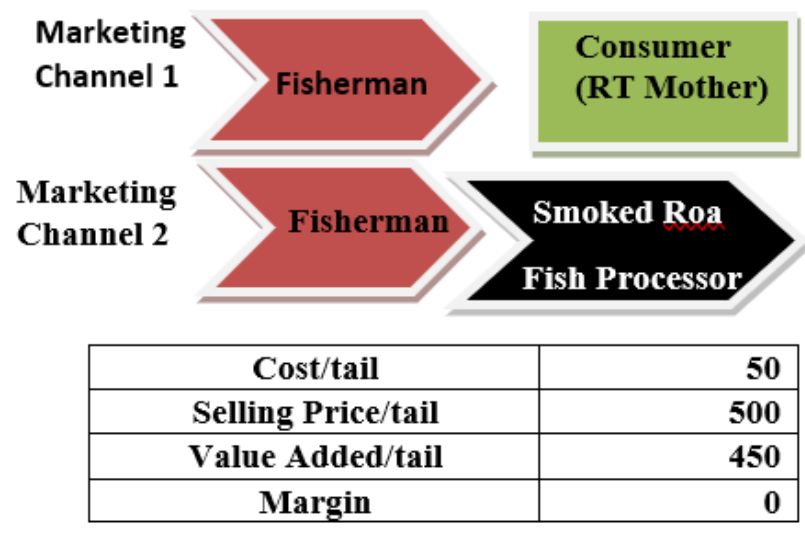

Fig.1. Marketing Margin Analysis of Fresh Julung-Julung

Fish

In Figure 1 there are 2 marketing channels for fresh julung-julung fish caught by fishermen 1 , namely from fishermen to final consumers (housewives) or channel 2, namely from fishermen to UPI (Fish Processing Unit). The selling price of the fishermen is the same, which is Rp. 500, - per fish. There are no marketing costs because they are directly sold on the beach when the boat is docked. Thus, it can be seen in Figure 1 that the added value or profit obtained by fishermen per fresh julung-julung fish is the same, namely Rp. 450, -. While the margin is 0 because the price paid by consumers is the same as that received by producers, namely Rp. 500, This is a very efficient marketing channel because it is the shortest channel and the margin is 0 .

\section{Marketing Margin at the Smoked Julung-Julung Processor level}

The costs incurred by the Smoked Julung-Julung Fish Processor consist of fixed costs and variable costs. Fixed costs are only in the form of depreciation of the smoking room measuring $6 \mathrm{~m} \times 10 \mathrm{~m}$, which costs $\mathrm{Rp}$. $10,000,000$ to manufacture, which can be used for up to 20 years so that the amount of depreciation per year is Rp. 500,000 ,- and the depreciation per month is Rp. 41,667, in a month. The production process is carried out 24 times so that the amount of depreciation per production is $\mathrm{Rp}$. $1.750,-$. For more clarity, it can be seen in table 4
Table. 4. Costs incurred in the Processing Business of Smoked Julung-Julung Fish per production with an average production of 150 pins

\begin{tabular}{llr}
\hline No & Description & \multicolumn{1}{c}{$\begin{array}{r}\text { Variable } \\
\text { Costs (Rp) }\end{array}$} \\
\hline & Fixed Cost (Depreciation) & $\mathbf{1 . 7 5 0}$ \\
\hline & Variable Cost & \\
\hline 1 & Raw Material (Rp.500,-./head) & $\mathbf{1 . 5 0 0 . 0 0 0}$ \\
2 & Wage clamp (Rp.500,-/pin) & $\mathbf{7 5 . 0 0 0}$ \\
3 & Smoker wages (Rp.750,-/pin) & $\mathbf{1 1 2 . 5 0 0}$ \\
4 & Bamboo tongs (Rp.500,-/pin) & $\mathbf{7 5 . 0 0 0}$ \\
5 & Firewood & $\mathbf{2 5 . 0 0 0}$ \\
\hline \multicolumn{3}{c}{ Total Cost/Production } \\
\hline \multicolumn{3}{c}{ Total Cost/Pinch }
\end{tabular}

Source: Primary data, 2020

In table 4 it can be seen that the costs incurred in the Smoked Julung-Julung Fish Processing Business per production with an average production of 150 flops is Rp. 1.789.250, -. Thus, the production cost of smoked julungjulung fish per pin is Rp. 12,000,-. The production results in the form of smoked julung-julung fish are sold for Rp. 20,000 , - per pin and marketing costs in the form of sea transportation to Likupang are Rp. 100,000, - and eating and drinking coffee and cakes are Rp. 30,000, - so that the total marketing costs incurred producer as much as Rp. 130.000,-. In one marketing, an average of 1000 pins of smoked julung-julung fish are brought in. Thus, the marketing cost per tweezers incurred by the smoked julung-julung producer is Rp. 130, - so that the profit or margin obtained by the smoked julung-julung producer is Rp. 7,870, - per flop. For more details, the production costs of smoked julung-julung fish per pin and their marketing costs can be seen in table 5 .

Table. 5. Production and marketing costs of smoked julung-julung per pinch

\begin{tabular}{clr}
\hline No & Description & Cost $(\mathbf{R p )}$ \\
\hline 1 & Production Cost/clamp & $\mathbf{1 2 . 0 0 0}$ \\
2 & Marketing Fee/pinch & $\mathbf{1 3 0}$ \\
3 & Modal / clamp & $\mathbf{1 2 . 1 3 0}$ \\
4 & Price/clamp & $\mathbf{2 0 . 0 0 0}$ \\
5 & Manufacturer profit & $\mathbf{7 . 8 7 0}$ \\
\hline
\end{tabular}

Source: Primary data, 2020 


\section{Marketing Margin at Brokerage level}

The costs incurred at the intermediary level vary depending on the marketing area, in general the brokerage fees incurred are only for vehicle rental costs and meals. Based on the results of interviews with respondents from intermediary traders from Bitung and Manado, the cost for renting a pick-up vehicle is the same, namely $\mathrm{Rp}$. 250,000 and a meal of Rp. 25,000, with a load of 300 flops for those in Bitung and 500 flops for those in Manado. Thus the cost at the intermediary level per pin for the Bitung marketing area is Rp. 915, -, while for the Manado marketing area it is Rp. 550, -. For intermediary traders in Airmadidi only use 2-wheeled vehicles so that the costs incurred are only for gasoline costs of Rp. 25,000, - and only drinking coffee and cakes for Rp. 10,000 , - so a total of Rp. 35,000, -. Not much smoked Julung-Julung fish are transported, only 100 pins, so the cost per pin is Rp. 350,-- Finally, for middlemen in the marketing area of Tomohon, the cost of renting a vehicle is up to Rp. 400,000, - and eating 2 people is Rp. 50,000, - so the total cost is Rp. 450,000, - while the smoked Julung-Julung fish that are transported reach 500 pins. Thus the cost per pin is Rp.900,-. For more details can be seen in table

6.

Table 6: Marketing costs per pinch at the intermediary level per marketing area

\begin{tabular}{llrrrr}
\hline No. & Information & Bitung & Airmadidi & \multicolumn{1}{l}{ Manado } & \multicolumn{1}{l}{ Tomohon } \\
\hline 1 & Vehicle Rental (Rp) & 250.000 & 25.000 & 250.000 & 400.000 \\
2 & Meal/ coffee+cake (Rp) & 25.000 & 10.000 & 25.000 & 50.000 \\
3 & Total (Rp) & 275.000 & 35.000 & 275.000 & 450.000 \\
4 & Transported goods (Clamp) & 300 & 100 & 500 & 500 \\
5 & Cost per clip (Rp) & 915 & 350 & 550 & 900 \\
6 & Purchase price per clip(Rp) & 20,000 & 20,000 & 20,000 & 20,000 \\
7 & Capital per pinch & 20,915 & 20,350 & 20,550 & 20,900 \\
8 & Selling price per clip (Rp) & 26,000 & 25,000 & 26,000 & 27,000 \\
9 & Margin at brokerage level (Rp) & $\mathbf{5 . 0 8 5}$ & $\mathbf{4 . 6 5 0}$ & $\mathbf{5 . 4 5 0}$ & $\mathbf{6 . 1 0 0}$ \\
\hline
\end{tabular}

Source: Primary Data Processed, 2020

\section{Marketing Margin at Merchant Retailer level}

Retailers who are used as respondents are retailers who are marketed in their marketing areas. The costs incurred by retailers who are in the market are generally only costs for eating and drinking because smoked julung-julung fish are delivered by intermediary traders directly based on orders. The cost for eating and drinking coffee and cake per day for retailers in the market is the same in all marketing areas, which is Rp. 30,000, - because that is the general standard in North Sulawesi. However, the price at each retailer varies according to the marketing area. The average smoked julung-julung retailer in the market not only sells smoked julung-julung but also sells almost all kinds of salted fish so that the marketing costs cannot be charged to the sale of smoked julung-julung only but to share with other kinds of processed fish. other. The retailer of smoked julung-julung fish sells about 20 types of salted fish from various types of anchovies to various types of salted reef fish with various levels of selling prices. Therefore, in the analysis of marketing costs by retailers per type of fish, it is obtained that Rp. 30,000, - is divided by 20 types of fish sold so that per type is charged a fee of Rp. 1,500, - Likewise, Smoked Julung-Julung Fish which is successfully sold by each trader. retailers are not the same, this will affect the marketing costs per pin. For more details on marketing costs per pin and margin at the retailer level per marketing area can be seen in table 7 .

Table 7: Marketing costs per pinch at the retailer level per marketing area

\begin{tabular}{llrrrr}
\hline No. & Information & Bitung & Airmadidi & Manado & \multicolumn{2}{c}{ Tomohon } \\
\hline 1 & Marketing cost/day (Rp) & 1.500 & 1.500 & 1.500 & 1.500 \\
2 & Average sold/day (Pinch) & 20 & 10 & 20 & 15 \\
3 & Marketing fee/pin (Rp) & 75 & 150 & 75 & 100 \\
4 & Purchase price per clip (Rp) & 26,000 & 25,000 & 26,000 & 27,000
\end{tabular}




\begin{tabular}{|c|c|c|c|c|c|}
\hline 5 & Capital per pin (Rp) & 26,075 & 25,150 & 26,075 & 27,100 \\
\hline 6 & Selling price per clip(Rp) & 30.000 & 28,500 & 30,000 & 32,000 \\
\hline & Margin at Brokerage level (Rp) & 3.925 & 3.350 & 3.925 & 4.900 \\
\hline
\end{tabular}

Source: Primary Data Processed, 2020

\section{Smoked Scallops Marketing Channel}

There are 4 marketing channels for smoked julung-julung fish from Kinabuhutan Village, namely

\section{a. Marketing Channel 1}

Channel Marketing 1 Smoked Julung fish

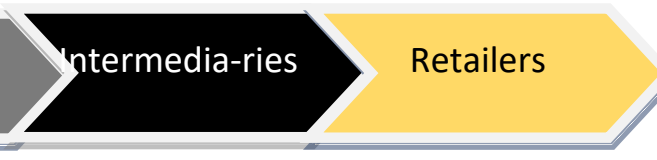

\section{Consumers}

\begin{tabular}{|l|r|r|r|}
\hline Charges/pins & 12.130 & 20,915 & 26,075 \\
\hline price/clamp & 20.000 & 26.000 & 30.000 \\
\hline Value Added/clamp & 7.870 & 5.085 & 3.925 \\
\hline Margin & \multicolumn{3}{|c|}{10.000} \\
\hline
\end{tabular}

\begin{tabular}{|l|r|r|r|}
\hline Charges/pins & 12.130 & 20,350 & 25,150 \\
\hline price/clamp & 20.000 & 25.000 & 28.500 \\
\hline Value Added/clamp & 7.870 & 4.650 & 3.350 \\
\hline Margin & \multicolumn{3}{|c|}{8.500} \\
\hline
\end{tabular}

\begin{tabular}{|l|r|r|r|}
\hline Charges/pins & 12.130 & 20,550 & 26,075 \\
\hline price/clamp & 20.000 & 26.000 & 30.000 \\
\hline Value Added/clamp & 7.870 & 5.450 & 3.925 \\
\hline Margin & \multicolumn{3}{|c|}{10.000} \\
\hline
\end{tabular}

\begin{tabular}{|l|r|r|r|}
\hline Charges/pins & 12.130 & 20,900 & 27,100 \\
\hline price/clamp & 20.000 & 27.000 & 32.000 \\
\hline Value Added/clamp & 7.870 & 6.100 & 4.900 \\
\hline Margin & \multicolumn{3}{|c|}{12.000} \\
\hline
\end{tabular}

Fig.2. Margin Analysis on Marketing Channels 1 Smoked Julung-Julung Fish in Each Marketing Area 
b. Marketing Channel 2

Channel

Marketing 2

Smoked Julung

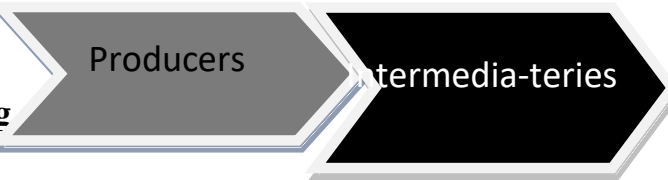

\section{Consumers}

fish

\begin{tabular}{|l|r|r|}
\hline Charges/pins & 12.130 & 20,915 \\
\hline price/clamp & 20.000 & 26.000 \\
\hline Value Added/clamp & 7.870 & 5.085 \\
\hline Margin & \multicolumn{3}{|c|}{6.000} \\
\hline
\end{tabular}

\begin{tabular}{|l|r|r|}
\hline Charges/pins & 12.130 & 20,350 \\
\hline price/clamp & 20.000 & 25.000 \\
\hline Value Added/clamp & 7.870 & 4.650 \\
\hline Margin & \multicolumn{2}{|c|}{5.000} \\
\hline
\end{tabular}

\begin{tabular}{|l|r|r|}
\hline Charges/pins & 12.130 & 20,550 \\
\hline price/clamp & 20.000 & 26.000 \\
\hline Value Added/clamp & 7.870 & 5.450 \\
\hline Margin & \multicolumn{3}{|c|}{6.000} \\
\hline
\end{tabular}

\begin{tabular}{|l|r|r|}
\hline Charges/pins & 12.130 & 20,900 \\
\hline price/clamp & 20.000 & 27.000 \\
\hline Value Added/clamp & 7.870 & 6.100 \\
\hline Margin & \multicolumn{2}{|c|}{7.000} \\
\hline
\end{tabular}

Figure 3. Margin Analysis on Marketing Channels 2 Smoked Julung-Julung Fish in each marketing area

c. Marketing Channel 3

Channel

Marketing 3

Smoked Julung

fish

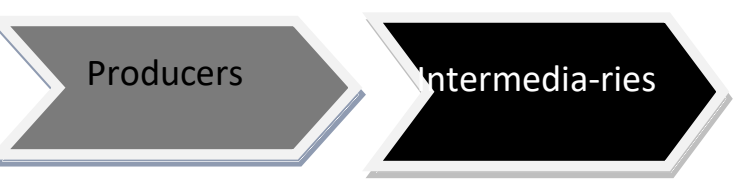

Consumers

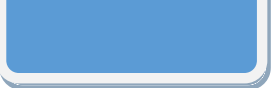

\begin{tabular}{|l|r|r|}
\hline Charges/pins & 12.130 & 20.150 \\
\hline price/clamp & 20.000 & 25.000 \\
\hline Value Added/clamp & 7.870 & 4.850 \\
\hline Margin & \multicolumn{2}{|c|}{5.000} \\
\hline
\end{tabular}

Fig.4. Margin Analysis on Marketing Channels 3 Smoked Julung-Julung Fish that only exist in the Likupang marketing area 
d. Marketing Channel 4

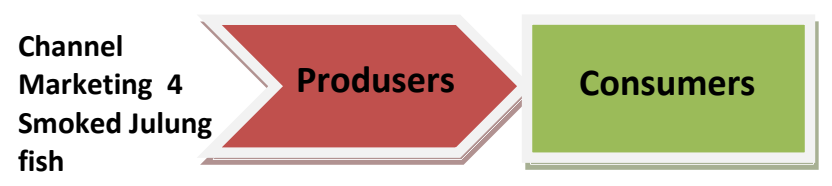

\begin{tabular}{|c|r|}
\hline Charges/pins & 12.000 \\
\hline price/clamp & 20.000 \\
\hline Value Added/clamp & $\mathbf{8 . 0 0 0}$ \\
\hline Margin & 0 \\
\hline
\end{tabular}

Fig.5. Margin Analysis on Marketing Channels 4 Smoked Julung-Julung Fish that only exist in the Kinabuhutan marketing area

The results of the marketing margin analysis of smoked julung-julung fish show that channel 4 is the most efficient channel because what consumers pay is the same as what the producer receives, which means the marketer's margin is 0 . The 2nd and 3rd marketing channels are the next efficient marketing channels and the one that is the most efficient. The least efficient is marketing channel 1 because the marketing channel is Table 8. Marketing Margin of Fresh Julung-Julung Fish and Fisherman's share in Kinabuhutan Marketing Area

\section{Fisherman's Share}

long so the marketing margin is big. Based on the marketing area, the most efficient marketing area is the one in Kinabuhutan because it is in the production area while the least efficient is the marketing area of Tomohon City because the largest marketing margin is Rp. 12,000,

Fisherman's Share Analysis This analysis is used to compare the price received by fishermen with the price paid by the final consumer (Limbong and Sitorus 1987). According to Kohls and Uhl (1990) if the share received by fishermen is less than 50 percent, it can be said that the marketing system is not efficient, and Azzaino (1983) suggests that the longer the marketing chain or the number of traders, the greater the marketing costs. This results in a larger marketing margin so that the price received by fishermen is getting smaller.

\begin{tabular}{|c|c|c|c|c|}
\hline \multirow[b]{2}{*}{ Description } & \multirow[b]{2}{*}{$\begin{array}{l}\text { Selling price of } \\
\text { fishermen } / 20 \text { fish (Rp) }\end{array}$} & \multicolumn{3}{|c|}{ KINABUHUTAN } \\
\hline & & $\begin{array}{l}\text { Consumer buying } \\
\text { price( }(\mathbf{R})\end{array}$ & $\begin{array}{c}\text { Marketing Margin } \\
\text { (Rp) }\end{array}$ & $\begin{array}{c}\text { Fisherman's share } \\
(\%)\end{array}$ \\
\hline Channel 1 & 10.000 & 10.000 & $\mathbf{0}$ & 100 \\
\hline Channel 2 & 10.000 & 10.000 & $\mathbf{0}$ & 100 \\
\hline
\end{tabular}

Source: Primary Data Processed, 2020

Table 8 shows that the marketing margin is 0 on all channels, because the price paid by consumers is the same as that received by fishermen. Thus the Fisherman's share becomes $100 \%$, it can be concluded that the marketing of Fresh Julung-Julung Fish is very efficient.

Margin and Fisherman's share in the marketing of smoked julung-julung fish as shown in table 9.

Table 9. Marketing Margin of Smoked Crayfish and Fisherman's share in Each Marketing Area

\begin{tabular}{|c|c|c|c|c|}
\hline \multirow[b]{2}{*}{ Description } & \multirow[b]{2}{*}{$\begin{array}{l}\text { Selling price of } \\
\text { fishermen } / 20 \text { fish } \\
(\mathbf{R p})\end{array}$} & \multicolumn{2}{|r|}{ BITUNG } & \multirow[b]{2}{*}{$\begin{array}{c}\text { Fisherman's share } \\
(\%)\end{array}$} \\
\hline & & $\begin{array}{l}\text { Consumer buying } \\
\text { price (Rp) }\end{array}$ & $\begin{array}{c}\text { Marketing Margin } \\
\text { (Rp) }\end{array}$ & \\
\hline Channel 1 & 10.000 & 30.000 & 20.000 & 33 \\
\hline Channel 2 & 10.000 & 26.000 & 16.000 & 38,5 \\
\hline \multirow[b]{2}{*}{ Description } & \multirow[b]{2}{*}{$\begin{array}{l}\text { Selling price of fishermen } \\
\text { /20 fish }(\mathrm{Rp})\end{array}$} & & AIRMADIDI & \\
\hline & & $\begin{array}{l}\text { Consumer buying } \\
\text { price }(\mathrm{Rp})\end{array}$ & $\begin{array}{c}\text { Marketing Margin } \\
(\mathrm{Rp})\end{array}$ & $\begin{array}{l}\text { Fisherman's share } \\
\qquad \%)\end{array}$ \\
\hline
\end{tabular}




\begin{tabular}{|c|c|c|c|c|}
\hline Channel 1 & 10.000 & 28.500 & 18.500 & 35 \\
\hline Channel 2 & 10.000 & 26.000 & 16.000 & 38,5 \\
\hline \multirow[b]{2}{*}{ Description } & \multirow[b]{2}{*}{$\begin{array}{l}\text { Selling price of fishermen } \\
\text { /20 fish }(\mathrm{Rp})\end{array}$} & \multicolumn{3}{|c|}{ MANADO } \\
\hline & & $\begin{array}{l}\text { Consumer buying } \\
\text { price }(\mathrm{Rp})\end{array}$ & $\begin{array}{c}\text { Marketing Margin } \\
\text { (Rp) }\end{array}$ & $\begin{array}{c}\text { Fisherman's share } \\
\qquad(\%)\end{array}$ \\
\hline Channel 1 & 10.000 & 30.000 & 20.000 & 33 \\
\hline Channel 2 & 10.000 & 26.000 & 16.000 & 38,5 \\
\hline \multirow[b]{2}{*}{ Description } & \multirow[b]{2}{*}{$\begin{array}{l}\text { Selling price of fishermen } \\
\text { /20 fish (Rp) }\end{array}$} & \multicolumn{3}{|c|}{ TOMOHON } \\
\hline & & $\begin{array}{l}\text { Consumer buying } \\
\text { price }(\mathrm{Rp})\end{array}$ & $\begin{array}{l}\text { Marketing Margin } \\
\text { (Rp) }\end{array}$ & $\begin{array}{c}\text { Fisherman's share } \\
(\%)\end{array}$ \\
\hline Channel 1 & 10.000 & 32.000 & 22.000 & 31 \\
\hline \multirow[t]{2}{*}{ Channel 2} & 10.000 & 27.000 & 17.000 & 37 \\
\hline & & \multicolumn{3}{|c|}{ LIKUPANG } \\
\hline Description & $\begin{array}{l}\text { Selling price of fishermen } \\
\text { /20 fish (Rp) }\end{array}$ & $\begin{array}{l}\text { Consumer buying } \\
\text { price }(\mathrm{Rp})\end{array}$ & $\begin{array}{c}\text { Marketing Margin } \\
\text { (Rp) }\end{array}$ & $\begin{array}{c}\text { Fisherman's share } \\
(\%)\end{array}$ \\
\hline \multirow[t]{2}{*}{ Channel 3} & 10.000 & 25.000 & 20.000 & 40 \\
\hline & & \multicolumn{3}{|c|}{ KINABUHUTAN } \\
\hline Description & $\begin{array}{l}\text { Selling price of fishermen } \\
\text { /20 fish (Rp) }\end{array}$ & $\begin{array}{l}\text { Consumer buying } \\
\text { price }(\mathrm{Rp})\end{array}$ & $\begin{array}{c}\text { Marketing Margin } \\
\text { (Rp) }\end{array}$ & $\begin{array}{c}\text { Fisherman's share } \\
(\%)\end{array}$ \\
\hline Channel 4 & 10.000 & 20.000 & 10.000 & 50 \\
\hline
\end{tabular}

Source: Primary Data Processed, 2020

Table 9 shows that in all channels the margins are very large and Fisherman's share is all $<50 \%$, which means that the Julung-Julung Asap fish marketing channel is not efficient, this is because it has gone through the processing process so that the prices received by fishermen and those paid by consumers are very large. the difference, or the marketing margin will be big.

\section{CONCLUSION}

From the results of the analysis, the following conclusions can be drawn:

(1). There are 2 marketing channels for fresh julung-julung fish, but both are very efficient because the marketing margin is 0 . There are 4 marketing channels for smoked julung-julung fish, the first from producers to middlemen then to retailers in the market directly to consumers. The second channel is from producers to middlemen and directly to consumers. The third channel is from producers to retailers and then directly to consumers. The fourth channel is from producers directly to consumers.

(2). The result of marketing margin analysis of smoked julung-julung fish is that the farther the distance between producers and consumers, the longer the marketing channel and the larger the marketing margin, making it more inefficient. In this study, the marketing channel no. 1 with the marketing area to Tomohon is inefficient because the price paid by the final consumer is the most expensive so that the largest marketing margin is Rp. 12,000,-. While the most efficient which is marketed in the production area is channel 4 because the margin is 0 .

(3). The added value or share received by fishermen is Rp.4,500,- per 20 fish, fish processing producers are Rp.7,850,- per pin, while intermediary traders and retailers vary according to the marketing area.

(4). Marketing margins on all marketing channels of Fresh Julung-Julung Fish are very efficient, because the price paid by consumers is the same as that received by fishermen. Thus the margin is 0 and Fisherman's share is $100 \%$. On the other hand, in all marketing channels of Smoked Julung-Julung fish, the margin is very large and all Fisherman's shares are $<50 \%$, which means that Smoked Julung-Julung fish marketing channels are inefficient, 


\section{REFERENCES}

[1] Anggadiredja, J.T. 2007.Potential and Prospect of Indonesia Seaweed Industry Development.The Indonesia Agency for the Assessment and Application of TechnologyIndonesia Seaweed Society. Jakarta.

[2] Anindita, R. 2003. Dasar-dasar Pemasaran Hasil Pertanian.Jurusan Sosial Ekonomi Unibraw Malang.

[3] Azzaino, Z., 1983, Pengantar Tataniaga Pertanian, Departemen Ilmu-ilmu Sosial Pertanian, Fakultas Pertanian Institut Pertanian Bogor, Bogor

[4] Bawinto, O.Y., Suhaeni, S., Wagiu, M. 2016. Sistem Pemasaran Ikan Cakalang Fufu di Kelurahan Sindulang Satu Kota Manado. Akulturasi (Jurnal Agrobisnis Perikanan). UNSRAT

[5] Hanafiah AM dan AM Saefudin. 1983. Tataniaga Hasil Perikanan. UI Press. Jakarta

[6] Kusnawati, A., 2013. Rantai Nilai (Value Chain) Agribisnis Labu di Kecamatan Getasan Kabupaten Semarang. Skripsi. Fakultas Ekonomi dan Bisnis Universitas Diponegoro. Semarang.

[7] Kohls, R.L., dan J.N. Uhl, 1990, Marketing of Agricultural Product (Seventh Edition), Collier Macmillan Publishing Company. New York

[8] Mangifera, L. 2015. Analisis Rantai Nilai (Value Chain) pada Produk Batik Tulis di Surakarta. Skripsi. Program Studi Magister Manajemen Universitas Muhammadiyah Surakarta

[9] Najamudin. 2014. Pemanfaatan Sumber Daya Ikan Layang (Decapterus spp) Berkelanjutan di Perairan Selat Makasar. IPB Press, Bogor

[10] Nasution, S. 2003. Metode Research (Penelitian Ilmiah). Edisi Pertama. Bumi Aksara. Jakarta.

[11] Pearce dan Robinson, 2008. Manajemen Strategis: Formulasi, Implementasi dan Pengendalian. Jakarta: Salemba Empat

[12] Retno Muninggar, Ernani Lubis, Anwar Bey Pane. 2013. Pemasaran Hasil Tangkapan Dan Kebijakan PUMP Di PPN Palabuhanratu (Fish Marketing And Pump Policy At Palabuhanratu Fishing Port). BULETIN PSP ISSN: 0251286X Volume 21 No. 1 Edisi April 2013 Hal 107-118

[13] Sondakh S., Soemarno, N. Harahap, S. Berhimpon, 2014. The Development Of A Livelihood Alternative Based On Marine Service In Manado CityJournal of Research in Environmental and Earth Science Volume $1 \sim$ Issue 4 (2014) pp: 16-21 ISSN(Online) : 2348-2532 www.questjournals.org

[14] Sondakh, S. dan Suhaeni, S. 2017. PKM kelompok PKK dalam meningkatkan ekonomi keluarga di Kelurahan Sario Utara Kota Manado Sulawesi Utara. https://ejournal.unsrat.ac.id/index.php/akulturasi

[15] Sondakh, S., Soemarno, Nuddin, H., Berhimpon, S. 2014. Pengembangan Alternatif Mata Pencaharian Nelayan Berbasis Jasa Kelautan di Manado. UB, Malang

[16] Suhaeni S., Soemarno, Nuddin Harahap, S. Berhimpon. 2014. The Empowerment Model Of Skipjack Tuna Fish (Cakalang Fufu) Processing Small Industry In Bitung City.Journal of Research in Environmental and Earth
Volume 1 Issue 4 2014) pp: 09-151SSN (Online) :23482532 www.questjournals.org

[17] Suhaeni, S. Dan Wigati, H., 2004. Pemasaran Hasil Perikanan di Kota Bitung. FPIK Suhaeni S., Sondakh S. (2018) PKM Kelurahan Sario Utara Kota Manado dalam pemberdayaan ibu rumah tangga Nelayan. Jurnal Akulturasi ISSN 2337-4195

[18] Sondakh, S. Soemarno, N. Harahab, S. Berhimpon (2014). The Development of Livelihood Alternatif Based on marine service in Manado City Journal of Reseach in environmental and Earth Science Vol. 1 ISSN 2348-2532. www.questjournals.org

[19] Sondakh, S dan Siti Suhaeni (2018) PKM Kelompok PKK Desa Lotta Kecamatan Pineleng Kabupaten Minahasa, Propinsi Sulawesi Utara tentang Pengelolaan Bakso Ikan dalam Meningkatkan Kemampuan berwira Usaha. Jurnal Akulturasi ISSN 2337-41 